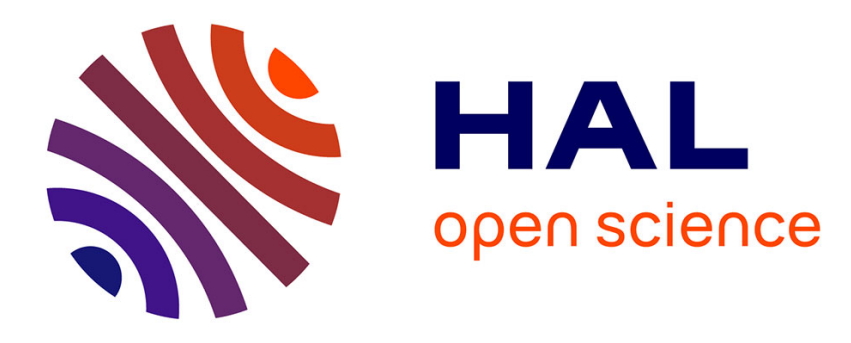

\title{
Tropical pathways, equatorial undercurrent variability and the 1998 La Niña
}

\author{
Takeshi Izumo, Joël Picaut, Bruno Blanke
}

\section{To cite this version:}

Takeshi Izumo, Joël Picaut, Bruno Blanke. Tropical pathways, equatorial undercurrent variability and the 1998 La Niña. Geophysical Research Letters, 2002, 29 (22), pp.37-1-37-4. 10.1029/2002GL015073 . hal-00172842

\section{HAL Id: hal-00172842 \\ https://hal.science/hal-00172842}

Submitted on 27 Jan 2021

HAL is a multi-disciplinary open access archive for the deposit and dissemination of scientific research documents, whether they are published or not. The documents may come from teaching and research institutions in France or abroad, or from public or private research centers.
L'archive ouverte pluridisciplinaire HAL, est destinée au dépôt et à la diffusion de documents scientifiques de niveau recherche, publiés ou non, émanant des établissements d'enseignement et de recherche français ou étrangers, des laboratoires publics ou privés. 


\title{
Tropical pathways, equatorial undercurrent variability and the 1998 La Niña
}

\author{
Takeshi Izumo \\ Université Paul Sabatier, Laboratoire d'Études en Géophysique et Océanographie Spatiales (LEGOS), Toulouse, France
}

Joel Picaut

Institut de Recherche pour le Développement, LEGOS, Toulouse, France

\author{
Bruno Blanke \\ Laboratoire de Physique des Océans (LPO), UFR Sciences et Techniques, Brest, France
}

Received 8 March 2002; accepted 3 June 2002; published 30 November 2002.

[1] In the equatorial Pacific Ocean, the rapid transition from the 1997 El Niño to the 1998 La Niña was associated with an outcrop of cold water appearing at the surface around $\left(0^{\circ}, 125^{\circ} \mathrm{W}\right)$ end of May 1998 . In a validated ocean general circulation model, the cold water of the outcrop appears to come from two pathways (one in each hemisphere) that connect the subtropics to the equatorial upwelling region through the western boundary currents and the Equatorial Undercurrent (EUC). The EUC and subtropics may have an influence on the rapid turn into La Niña in 1998. Large variations in transport (up to $60 \times 10^{6} \mathrm{~m}^{3} \mathrm{~s}^{-1}$ ) and in transport-weighted temperature (up to $3^{\circ} \mathrm{C}$ ) of the EUC are observed in TAO moored data and in the model. The rapid variability of EUC transport and transport-weighted temperature may interact with the long-term variability of the thermocline circulation linking the subtropics to the equator. INDEX TERMS: 4231 Oceanography: General: Equatorial oceanography; 4522 Oceanography: Physical: El Niño. Citation: Izumo, T., J. Picaut, and B. Blanke, Tropical pathways, equatorial undercurrent variability and the 1998 La Niña, Geophys. Res. Lett., 29(22), 2080, doi:10.1029/2002GL015073, 2002.

\section{Introduction}

[2] The El Niño-Southern Oscillation (ENSO) phenomenon in the equatorial Pacific Ocean has increased in frequency and intensity during the last decades. The 1997 El Niño was the strongest of the last century and the transition into La Niña in 1998 was very rapid. A sea surface temperature (SST) drop of $7^{\circ} \mathrm{C}$ over one month (May 1998) was observed at $\left(0^{\circ}, 125^{\circ} \mathrm{W}\right)$ [McPhaden, 1999]. This SST drop was unusually rapid compared to other El Niño-La Niña transitions.

[3] Cold SST in the eastern equatorial Pacific is usually explained by equatorial upwelling and horizontal advection by the South Equatorial Current of waters issued from the coastal and equatorial upwelling [Wyrtki, 1981]. The equatorial upwelling is fed zonally by the Equatorial Undercurrent (EUC) [Bryden and Brady, 1985], and meridionally by the geostrophic convergence. The EUC and equatorial upwelling are part of the shallow subtropical overturning cells (STCs) [McCreary and Lu, 1994]. STCs bring surface

Copyright 2002 by the American Geophysical Union. 0094-8276/02/2002GL015073 waters subducted in the subtropics into the EUC along the thermocline. The waters can flow up to the equator via western boundary currents or directly via the interior ocean. The connection between the subtropical and equatorial Pacific through STCs was proposed as a possible mechanism for the decadal modulation of ENSO. This involves decadal variation either in the temperature of the subducted waters [Gu and Philander, 1997] or in the transport of the STCs [Kleeman et al., 1999].

[4] The present paper focuses on the origin of the cold water that outcrops in May 1998 around $\left(0^{\circ}, 125^{\circ} \mathrm{W}\right)$, and on the related variations of the EUC, using a combination of observations and model results. An ocean general circulation model (OGCM) is first validated against in situ data. Backward trajectories are estimated in the model in order to find the origin of the cold water. The variability of EUC transport and transport weighted temperature, as defined by Bryden and Brady [1985], is quantified using the OGCM and in situ data (mostly from the Tropical Atmosphere and Ocean (TAO) array [McPhaden et al, 1998]). The potential link between EUC and STCs variabilities is finally discussed.

\section{Means of Study}

[5] The OGCM used in this study is a global version of the OPA (Océan PArallélisé) model [Madec and Imbard, 1996]. It has a $2^{\circ}$ zonal resolution, a meridional resolution varying from $1.9^{\circ}$ to $0.5^{\circ}$ at the equator, and 31 levels in the vertical, with the highest resolution $(10 \mathrm{~m})$ in the upper 120 $\mathrm{m}$. The model is first forced over 1982-99 with the wind stress of the NCEP reanalysis. The second simulation mostly used in this study is done by replacing the wind stress over the April 1992-December 1999 period, by a better product derived from the ERS scatterometers. Both simulations used the NCEP heat and freshwater fluxes and a relaxation toward Reynolds' SST.

[6] STCs' pathways are evidenced by trajectories of particles released and advected in the 3-D simulated currents averaged over 5 days [Blanke and Raynaud, 1997]. The currents are validated over 1993-99 with TAO moorings at the equator equipped with Acoustic Doppler Current Profiler (ADCP). Table 1 shows a good agreement between observations and model, with the lowest correlation at depth at $165^{\circ} \mathrm{E}$. The boundaries of the EUC are defined using a 
Table 1. Correlation and Rms Difference Between TAO Data and Model for the Zonal Current at the Equator and $165^{\circ} \mathrm{E}, 170^{\circ} \mathrm{W}$ and $140^{\circ} \mathrm{W}$

\begin{tabular}{|c|c|c|c|c|c|c|}
\hline \multirow[b]{2}{*}{ Depth (m) } & \multicolumn{2}{|c|}{$165^{\circ} \mathrm{E}$} & \multicolumn{2}{|c|}{$170^{\circ} \mathrm{W}$} & \multicolumn{2}{|c|}{$140^{\circ} \mathrm{W}$} \\
\hline & Corr. & $\begin{array}{l}\text { RmsDif } \\
\left(\mathrm{m} \mathrm{s}^{-1}\right)\end{array}$ & Corr. & $\begin{array}{l}\text { RmsDif } \\
\left(\mathrm{m} \mathrm{s}^{-1}\right)\end{array}$ & Corr. & $\begin{array}{l}\text { RmsDif } \\
\left(\mathrm{m} \mathrm{s}^{-1}\right)\end{array}$ \\
\hline 30 & 0.81 & 0.23 & 0.68 & 0.24 & 0.69 & 0.30 \\
\hline 80 & 0.65 & 0.25 & 0.81 & 0.27 & 0.80 & 0.33 \\
\hline 150 & 0.64 & 0.22 & 0.84 & 0.22 & 0.80 & 0.28 \\
\hline
\end{tabular}

combination of current, temperature and spatial criteria. In order to extrapolate the EUC transport from TAO data right at the equator, the zonal current is first integrated over the depth of the EUC. This vertically integrated value is then multiplied by a mean meridional length, estimated from the model $\left(430 \mathrm{~km}\right.$ at $170^{\circ} \mathrm{W}$ and $410 \mathrm{~km}$ at $\left.140^{\circ} \mathrm{W}\right)$. This extrapolation technique works well in the model, as shown in Table 2 and Figure 1a where the exact EUC transport (dashed line) and the extrapolated one (dotted line) almost overlap. This technique is also verified with in situ data. EUC transports (circles in Figure 1a) estimated from five meridional ADCP sections [Johnson et al., 2000] compare quite well with the transport extrapolated from TAO data (full line). These transports estimated from in situ data compare well with the exact and extrapolated EUC transports in the model (Figure 1a and Table 2). However, the model underestimates the EUC speed right at the equator, because of the too coarse meridional resolution. Section 4 of this paper uses the transport-weighted temperature of the EUC as defined by Bryden and Brady [1985]. It is calculated by integrating over the EUC the product of velocity and temperature, divided by the integrated velocity. In the model, the EUC temperatures obtained by integrating over the whole meridional section of the EUC (dashed line) or right at the equator over the depth of the EUC (dotted line) have almost the same anomalies (Figure $1 \mathrm{~b}$ and Table 2). The average values over 1993-99 are however different, with $16.9^{\circ} \mathrm{C}$ for the model over the full section, $18.5^{\circ} \mathrm{C}$ for the model at the equator and $19.5^{\circ} \mathrm{C}$ for TAO data at the equator. The EUC temperature anomaly (full line) can be extrapolated from TAO data right at the equator, and the comparison with the exact and extrapolated EUC temperature anomalies in the model is good (Figure $1 \mathrm{~b}$ and Table 2). The main discrepancies appear when the EUC is poorly separated from eastward currents in the mixed layer near the equator (i.e., in

Table 2. Correlation and Rms Difference for the Transport (U) and Transport-Weighted Temperature (T) of the EUC at $170^{\circ} \mathrm{W}$ and $140^{\circ} \mathrm{W}$ Between the Model Full Section ( $\mathrm{U}_{\text {model } / \text { sect }}$ and $\left.\mathrm{T}_{\text {model } / \mathrm{sect}}\right)$, the Model Extrapolated From the Equator to the Full Section $\left(\mathrm{U}_{\text {model/eq }}\right.$ and $\left.\mathrm{T}_{\text {model/eq }}\right)$ and the TAO Data Extrapolated From the Equator to the Full Section $\left(\mathrm{U}_{\mathrm{TAO}}\right.$ and $\left.\mathrm{T}_{\mathrm{TAO}}\right)$

\begin{tabular}{|c|c|c|c|c|}
\hline & \multicolumn{2}{|c|}{$170^{\circ} \mathrm{W}$} & \multicolumn{2}{|c|}{$140^{\circ} \mathrm{W}$} \\
\hline & Corr. & RmsDif & Corr. & RmsDif \\
\hline $\mathrm{U}_{\text {model/sect }} / \mathrm{U}_{\text {model/eq }}$ & 0.94 & $5 \mathrm{SV}$ & 0.95 & $6 \mathrm{~Sv}$ \\
\hline $\mathrm{U}_{\mathrm{TAO}} / \mathrm{U}_{\text {model } / \mathrm{eq}}$ & 0.94 & $9 \mathrm{~Sv}$ & 0.89 & $15 \mathrm{~Sv}$ \\
\hline $\mathrm{U}_{\text {model } / \mathrm{sect}} / \mathrm{U}_{\mathrm{TAO}}$ & 0.86 & $11 \mathrm{~Sv}$ & 0.88 & $20 \mathrm{~Sv}$ \\
\hline $\mathrm{T}_{\text {model } / \mathrm{sect}} / \mathrm{T}_{\text {model} / \mathrm{eq}}$ & 0.92 & $0.6^{\circ} \mathrm{C}$ & 0.96 & $0.4^{\circ} \mathrm{C}$ \\
\hline $\mathrm{T}_{\mathrm{TAO}} / \mathrm{T}_{\text {model } / \mathrm{eq}}$ & 0.82 & $0.8^{\circ} \mathrm{C}$ & 0.90 & $0.8^{\circ} \mathrm{C}$ \\
\hline $\mathrm{T}_{\text {model } / \text { sect }} / \mathrm{T}_{\mathrm{TAO}}$ & 0.82 & $0.7^{\circ} \mathrm{C}$ & 0.87 & $0.8^{\circ} \mathrm{C}$ \\
\hline
\end{tabular}
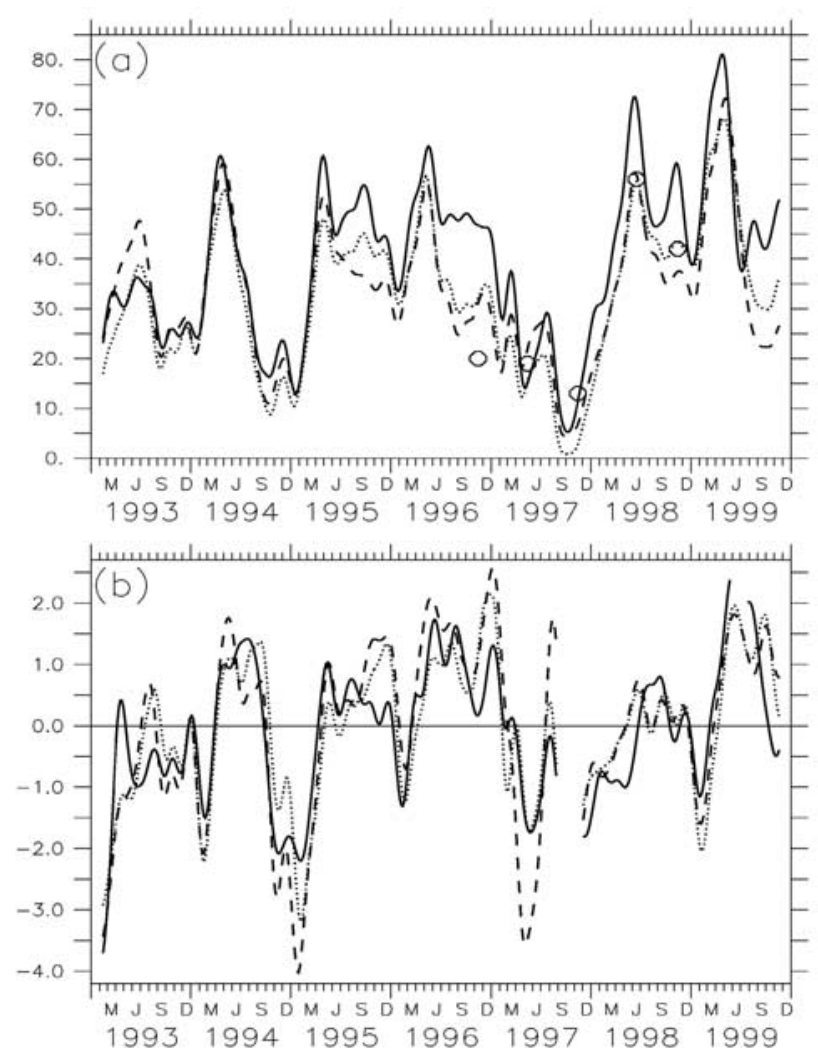

Figure 1. Variability in the EUC at $170^{\circ} \mathrm{W}$ : (a) EUC transport in Sverdrup $\left(1 \mathrm{~Sv}=10^{6} \mathrm{~m}^{3} \mathrm{~s}^{-1}\right)$, (b) anomaly of transport-weighted temperature of the EUC in ${ }^{\circ} \mathrm{C}$. Model full section (dashed line), extrapolation from the model at the equator to the full section (dotted line) and extrapolation from TAO data at the equator to the full section (full line). The transport from five ADCP sections (circles) is added on Figure 1a. For clarity, all series are low-pass filtered with a 3-month Hanning filter.

winter 1994, and spring and winter 1997). The successful meridional extrapolation from the equator to the whole EUC section of both EUC transport and temperature highlights the interest of ADCP moorings at the equator for studying the EUC transport and temperature variabilities.

\section{Origins of Outcropping Cold Water}

[7] The rapid transition into La Nina was obvious in the observations with a SST drop of $7^{\circ} \mathrm{C}$ from $29.5^{\circ} \mathrm{C}$ to $22.5^{\circ} \mathrm{C}$ over one month (May 1998) at $\left(0^{\circ}, 125^{\circ} \mathrm{W}\right)$. A patch of cold water associated with this drop appeared in Reynolds' SST around June 3, 1998 and $\left(0^{\circ}, 125^{\circ} \mathrm{W}\right)$. This patch colder than $23^{\circ} \mathrm{C}$ was trapped to the equator and squeezed between the western Pacific warm pool and the warm water spread all the way to the east during the strong 1997 El Niño [Picaut et al., 2002]. It is simulated in the model as a patch of SST colder than $24^{\circ} \mathrm{C}$ around June 7,1998 and $\left(0^{\circ}\right.$, $130^{\circ} \mathrm{W}$ ) (Figure 2). It is associated with a SST drop of $6^{\circ} \mathrm{C}$ (from $29.5^{\circ} \mathrm{C}$ to $23.5^{\circ} \mathrm{C}$ ) during May-early June 1998 . At this location, the $20^{\circ} \mathrm{C}$ isotherm, which was at its deepest level $(160 \mathrm{~m})$ in November 1997 , shoals to $50 \mathrm{~m}$ end of May 1998. Surfacing of the $24^{\circ} \mathrm{C}$ isotherm on June 7 seems related to upwelled water brought by the EUC (Figure 2b). 

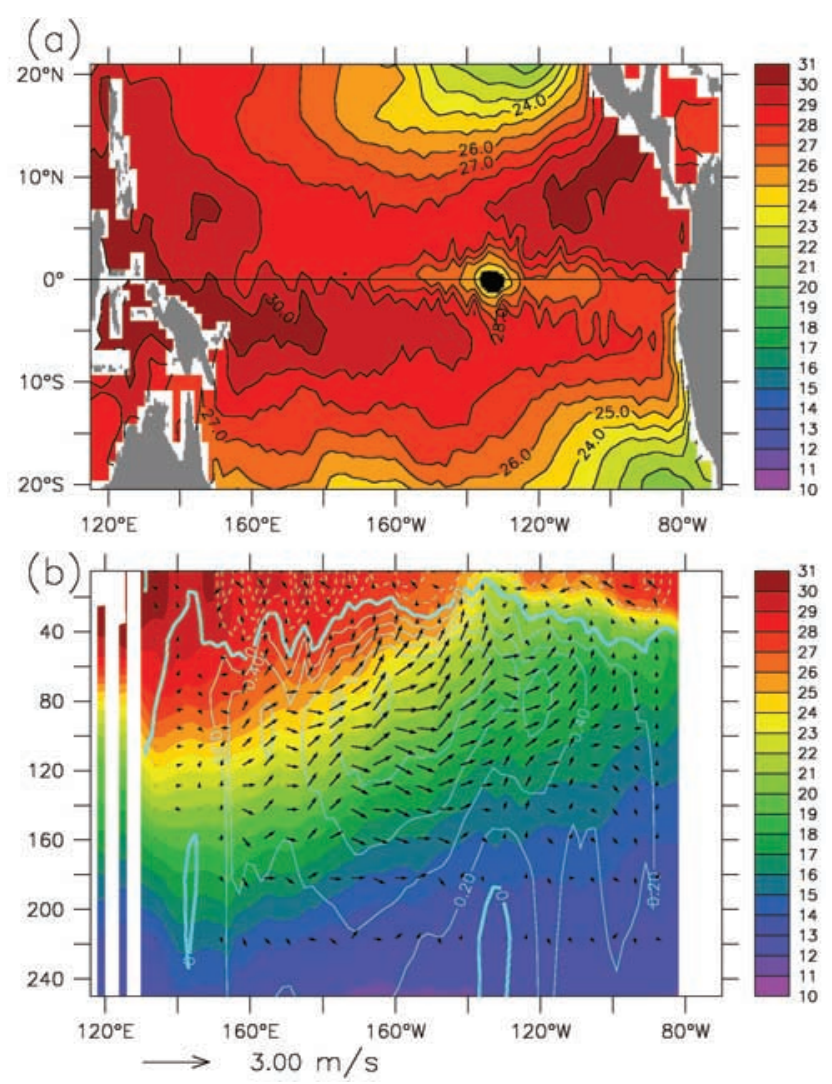

Figure 2. Model results on June 7, 1998: (a) SST over the tropical Pacific, (b) section along the equator over the first $250 \mathrm{~m}$. Colors represent the temperature in ${ }^{\circ} \mathrm{C}$, arrows the zonal and vertical currents and contours the zonal currents. The arrows have been rotated to compensate the difference in scaling between longitude and depth in the figure, while their magnitudes have been preserved (the arrow of reference corresponds to $3 \mathrm{~m} \mathrm{~s}^{-1}$ ). The patch of cold water (SST < $24^{\circ} \mathrm{C}$ ) where particles are launched is represented in black.

In order to investigate the origins of surfacing waters, more than a hundred of particles (128 particles) are launched at a depth of $5 \mathrm{~m}$, uniformly distributed in the patch of water colder than $24^{\circ} \mathrm{C}$ (Figure $2 \mathrm{a}$ ). In this region of strong mixing and others, water masses and not individual water particles are traced back, since mixing is a subgrid process in the model. Trajectories calculated backward in time from June 7, 1998 to January 1, 1993 evidence only two main pathways, with 61 (67) particles coming from the Southern (Northern) Hemisphere (Figure 3). In January 1993, the positions of the particles in the Northern Hemisphere are homogeneously spread, whereas two separate pathways appear in the Southern Hemisphere. The southern and northern pathways connect the subtropical thermocline to the equatorial upwelling region through the western boundary currents and the EUC. They are similar to the climatological pathways of STCs evidenced by Gu and Philander [1997], but none of the particles takes a direct pathway from the subtropics to the EUC through the interior ocean. In addition, no water originates from the eastern equatorial basin, or through meridional geostrophic convergence. Hence, it is interesting to note that all of the waters of the cold patch were brought by the EUC and the western boundary currents. However, one must keep in mind that such pathways may be sensitive to model resolutions and parameterizations. The simulation is not long enough to evidence the subduction of surface water in the subtropics, and in January 1993, the particles are still at 100-200 m depth in the subtropical gyres. On average, they take 3.5 years to reach the western boundaries, and three more months to reach the equatorial band at $150-200 \mathrm{~m}$. They are then transported eastward and upward by the EUC during approximately 20 months and upwelled in spring 1998 from $80 \mathrm{~m}$ depth to the mixed layer in about one month. Finally they moved to the southwest in the mixed layer by less than $100 \mathrm{~km}$ in May 1998, because of southwestward surface currents. This explains why all the trajectories in the EUC are concentrated north of the equator, and why more particles come from the northern hemisphere than in other studies [e.g., Blanke and Raynaud, 1997].

[8] In summary, the cold waters surfacing in the model around $\left(0^{\circ}, 130^{\circ} \mathrm{W}\right)$ in June 7,1998 were only brought by STCs via western boundary currents and the EUC. This particular scheme holds over the first three weeks of June. Similar experiments of particles launched in cold patches later and/or further east involve interior pathways and complicate recirculation patterns in the eastern tropical Pacific. Travel time and separate pathways in the western boundary currents must be interpreted with caution since these currents are misrepresented by the $2^{\circ}$ zonal resolution of the model. The other simulation forced with NCEP wind stress over 1982-99 gives similar results, except for a less realistic patch of cold water around $140^{\circ} \mathrm{W}$ in early June 1998 .
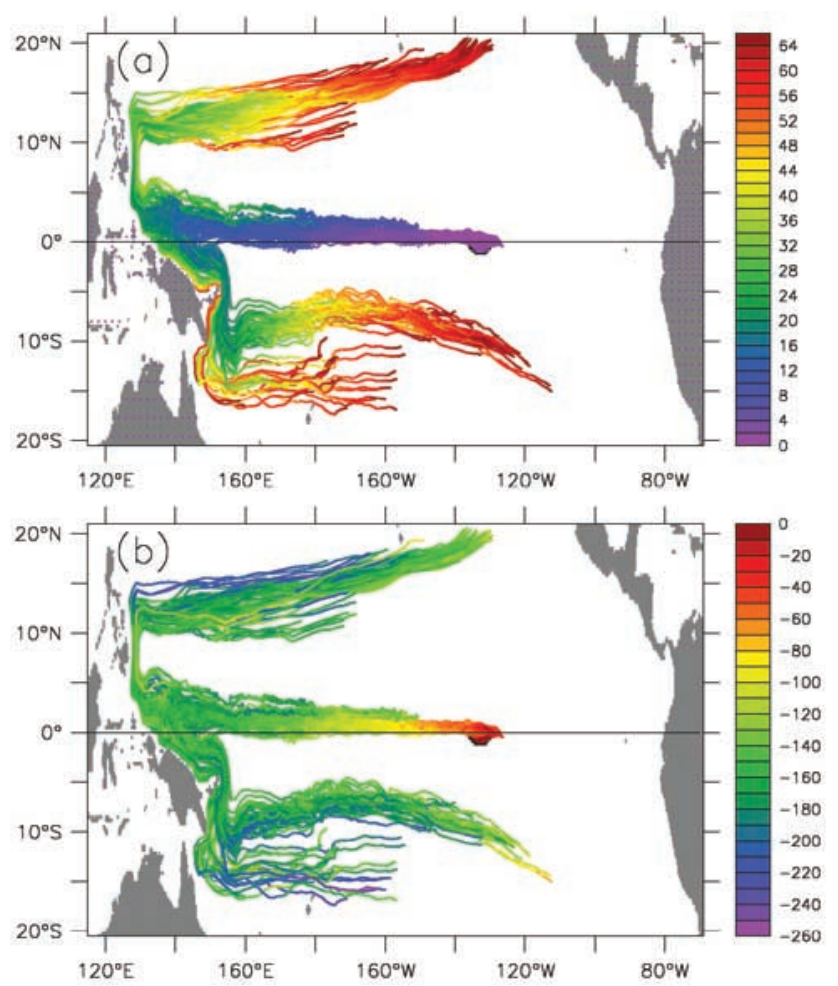

Figure 3. STCs pathways evidenced by the trajectories of 128 particles launched in the patch of cold water as seen on Figure $2 \mathrm{a}$. The color scales represent in the upper panel the time before June 1998 in month, and in the lower panel the depth of the trajectories in meter. 


\section{Transport and Temperature Variability of the EUC}

[9] EUC transport and transport-weighted temperature (hereafter defined as EUC temperature) variabilities at $170^{\circ} \mathrm{W}$ are shown on Figure 1. Note that the EUC temperature has no physical meaning when the EUC vanishes. Important variations of the transport (up to $60 \mathrm{~Sv}$ ) and temperature (up to $3^{\circ} \mathrm{C}$ ) are observed on various time scales and in particular on interannual time scale. Variations of the EUC transport are mostly related to the zonal pressure gradient within the thermocline [Johnson et al., 2000]. Variations of the EUC temperature are partly related to changes in the depth of the equatorial thermocline. For example, in 1996 prior to El Niño, the easterlies and zonal pressure gradient were strong and the thermocline was unusually deep. Thus, as shown on Figure 1 the EUC was strong (around $35 \mathrm{~Sv}$ ) and warm (about $1.5^{\circ} \mathrm{C}$ of anomaly). Over 1997, the EUC was weak and it even vanished for three months during the mature phase of El Niño. In addition, the EUC and its temperature were not well defined during most of the 1997 El Niño, because of the presence of an eastward surface current. In spring 1998, the EUC reappeared and was cold (about $-1.5^{\circ} \mathrm{C}$ of anomaly) when the easterlies strengthened and the thermocline shoaled west of $120^{\circ} \mathrm{W}$. During La Niña after mid-1998, the EUC was well established and very strong (around $50 \mathrm{~Sv}$ ). The variability of EUC transport and temperature at $140^{\circ} \mathrm{W}$ is similar, and it is not discussed here for sake of briefness.

\section{Discussion on the Turn into La Niña and the Long-Term Variations of STCS}

[10] Several processes are involved in the rapid turn into La Niña in May-June 1998. El Niño peaked in winter 1997-98, with warm waters covering the whole equatorial basin. At depth the thermocline slowly uplifted since October 1997, with a discharge of warm water from the equatorial zone consistent with the recharge-discharge mechanism [ Jin, 1997]. Upwelling Kelvin and Rossby waves emanating from both sides of the basin were important in pursuing this uplifting of the thermocline in spring 1998 [McPhaden and $Y u, 1999]$. Opposite surface currents associated with equatorial waves resulted in the break up of the warm waters around $\left(0^{\circ}, 130^{\circ} \mathrm{W}\right)$ starting in March 1998 [Picaut et al., 2002]. As shown in the model (Figure 2), this break-up of the warm waters led to a sudden arrival of cold water from below and a SST drop of $7^{\circ} \mathrm{C}$ in May 1998. Quite interestingly, in the model, all of this cold water can be tracked backward from both subtropics through the STCs and EUC.

[11] EUC transport and transport-weighted temperature variabilities are estimated using model and observations. Since the EUC is part of STCs, its variability could be influenced by the variability of the various branches that form the STCs. As noted in introduction, a hypothesis on the modulation of ENSO involves decadal variation in the temperature of waters subducted in the subtropics and transported equatorward by the mean circulation of STCs [Gu and Philander, 1997]. Another hypothesis involves decadal variation in the transport of STCs [Kleeman et al, 1999]. The thermal anomalies that could propagate in the northern tropical gyre from the subtropics toward the equator on decadal timescale are less than $0.6^{\circ} \mathrm{C}$ [Deser et al, 1996]. McPhaden and Zhang [2002] estimate the long-term variations in STCs' transport over the last 50 years and find a change of up to $14 \mathrm{~Sv}$, which could be related to decadal variations of SST in the central and eastern equatorial Pacific. As shown on Figure 2, on seasonal to interannual time scales, the variations of EUC transport and temperature can reach $60 \mathrm{~Sv}$ and $3^{\circ} \mathrm{C}$. The decadal variations of transport and temperature of the STCs might not be modified by these strong variations of the EUC. On the other hand, non-linear interactions between decadal and seasonal to interannual frequencies could distort and at last blur the weak decadal variations of transport and temperature. Further studies, using longer simulations and observations to access decadal variations of EUC and STCs, are necessary to understand the ambiguous link between EUC and STCs variations, and their possible impacts on the tropical Pacific climate.

[12] Acknowledgments. We thank G. Lorand for the model output used in the present analysis. This work was stimulated by the workshop on STCs organized by P. Rizzoli. Support was provided by CNES and PNEDC.

\section{References}

Blanke, B., and S. Raynaud, Kinematics of the Pacific Equatorial Undercurrent: An Eulerian and Lagrangian approach from GCM results, J. Phys. Oceanogr., 27, 1038-1053, 1997.

Bryden, H. L., and E. C. Brady, Diagnostic model of the three-dimensional circulation in the upper equatorial Pacific Ocean, J. Phys. Oceanogr., 15, $1255-1273,1985$.

Deser, C., M. A. Alexander, and M. S. Timlin, Upper-ocean thermal variations in the North Pacific during 1970-1991, J. Clim., 8, 1840-1855, 1996.

Gu, D. F., and S. G. H. Philander, Interdecadal climate fluctuations that depend on exchanges between the tropics and extratropics, Science, 275, $805-807,1997$.

Jin, F.-F., An Equatorial ocean recharge paradigm for ENSO. Part 1: Conceptual model, J. Atmos. Sci., 54, 811-829, 1997.

Johnson, G. C., M. J. McPhaden, G. D. Rowe, and K. E. McTaggart, Upper equatorial ocean current and salinity during the 1996-1998 El Niño-La Niña cycle, J. Geophys. Res., 105, 1037-1053, 2000.

Kleeman, R., J. P. McCreary, Jr., and B. A. Klinger, A mechanism for the decadal variation of ENSO, Geophys. Res. Lett., 26, 1743-1746, 1999.

Madec, G., and M. Imbard, A global ocean mesh to overcome the North Pole singularity, Clim. Dyn., 12, 381-388, 1996.

McCreary, J. P., and P. Lu, Interaction between the subtropical and equatorial ocean circulations - The subtropical cell, J. Phys. Oceanogr., 24, 455-497, 1994.

McPhaden, M. J., Genesis and evolution of the 1997-98 El Niño, Science, 283, 950-954, 1999.

McPhaden, M. J., and X. Yu, Equatorial waves and the 1997-98 El Niño, Geophys. Res. Lett., 26, 2961-2964, 1999.

McPhaden, M. J., and D. Zhang, Slowdown of the meridional overturning circulation in the upper Pacific Ocean, Nature, 415, 603-608, 2002.

McPhaden, M. J., et al., The Tropical Ocean Global Atmosphere (TOGA) observing system: A decade of progress, J. Geophys. Res., 103, 14,16914,240, 1998.

Picaut, J., E. Hackert, A. J. Busalacchi, R. Murtugudde, and G. S. E. Lagerloef, Mechanisms of the 1997-1998 El Niño-La Niña, as inferred from space-based observations, J. Geophys. Res., 107, 10.1029/2001JC000850, 2002.

Wyrtki, K., An estimate of equatorial upwelling in the Pacific, J. Phys. Oceanogr., 11, 1205-1214, 1981.

B. Blanke, LPO, UFR Sciences et Techniques, 6 avenue le Gorgeu, BP 809, 29285Brest, France. (Bruno.Blanke@univ-brest.fr)

T. Izumo, LEGOS, 18, avenue Edouard Belin, 31401 Toulouse cedex 4, France. (izumo@notos.cst.cnes.fr)

J. Picaut, LEGOS, 18, avenue Edouard Belin, 31401 Toulouse cedex 4, France. (Joel.Picaut@cnes.fr) 